SHADES OF BLACK 


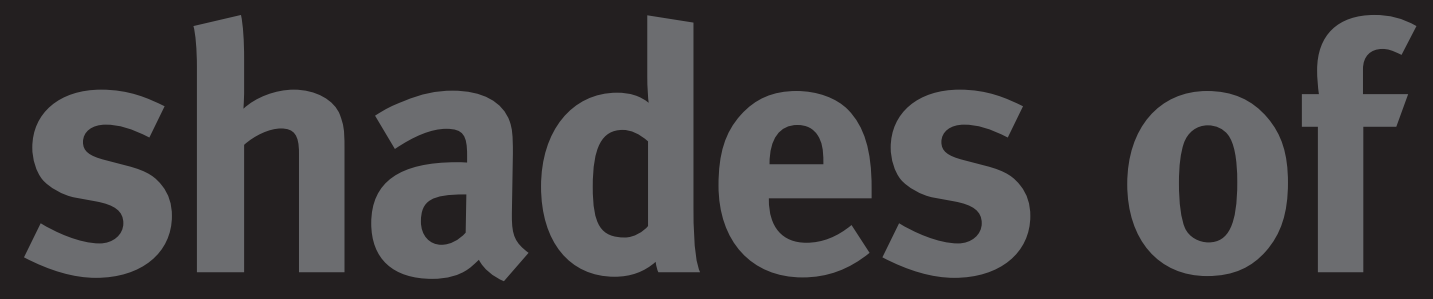


ASSEMBLING BLACK ARTS IN 1980 S BRITAIN
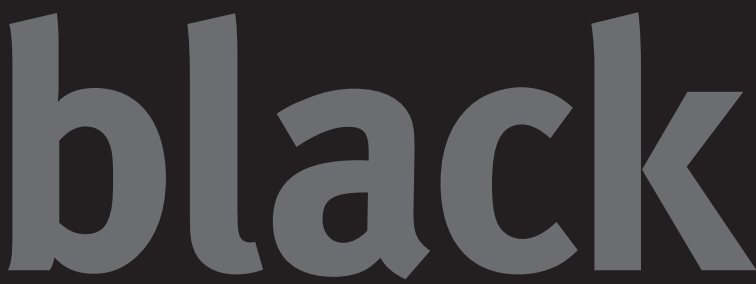

David A. Bailey, lan Baucom \& Sonia Boyce, editors

Duke University Press

Durham and London 2005

in collaboration with

the Institute of International

Visual Arts (inıvA) and

the African and Asian Visual

Artists' Archive (Aavaa) 
C) 2005 Duke University Press. All rights reserved. Printed in the United States of America on acid-free paper $\infty$ Designed by Rebecca Giménez. Typeset in Meta. Library of Congress Cataloging-in-Publication Data appear on the last printed page of this book.

\section{inIVA $\mathrm{Aa}$}

Published in collaboration with the Institute of International Visual Arts (inıvA) and the African and Asian Visual Artists' Archive (Aavaa).

Rasheed Araeen's essay “The Success and Failure of the Black Arts Movement” was originally published in Third Text 18, no. 2 (March 2004): 135-52. susan pui san lok's essay “A to Y (Entries for an Inventionry of Dented 'I's)” was originally published in Third Text 17 , no. 1 (March 2003): 63-71. These essays are reprinted courtesy of Taylor and Francis, http://www.tandf.co.uk/journals.

Both authors retain the copyright to their essays.

Duke University Press gratefully acknowledges the support of the Duke University Center for International Studies and the John Hope Franklin Center for Interdisciplinary and International Studies at Duke University, both of which provided funds toward the production of this book. 